\title{
LOOVKIRJUTISTE SÜNTAKSIMUUTUJATE ARENG TEISMEEAS
}

\author{
KRISTA KERGE, ANNE UUSEN, \\ HALLIKI PÕLDA, HELIN PUKSAND
}

\begin{abstract}
Annotatsioon. Õppida kirjutama tähendab õppida uut süntaksit. Kirjaoskuse ja keeleteadlikkuse üldises raamis (vt nt Ravid, Tolchinsky 2002) kajastab artikkel eestikeelse üldhariduskooli 5., 7., 9. ja 11. klassi õpilaste 159 arvamuskirjutise erinevusi omavahel ja võrreldes haritud mittefiloloogidest täiskasvanute toimetamata arvamuskirjutistega. Üldistused põhinevad üksikkirjutiste tekstimuutujatel kui süntaksiga seotud tunnustel, lubades võrrelda eakohaseid keskmisi, kõikumiste piire ja individuaalsete erinevuste suhtelist määra. Tulemused näitavad, et õpilane kirjutab 5. klassis lineaarselt üles oma mõtteid, nii et tekstiparameetrid sarnanevad mitmeti suulise kõne omadega. 7. klass erineb 5. klassist vaid tulemuste vähema hajususe poolest. Hüpe kirjalikus väljenduses toimub alles põhikooli lõpu eel; areng jätkub gümnaasiumis, saavutamata haritud täiskasvanu taset. Muutused võivad olla vähem või rohkem nii koolis suunatud keeleteadlikkuse ja kirjakogemuse kasvu tulemus kui ka kognitiivse arengu loomulik tagajärg, sest arengukõver sarnaneb varem leitutega (nt Nippold jt 2005; Alamargot jt 2010). Võtmesõnad: eesti keel, argumenteeriv tekst, kognitiivne ja keeleline areng, sõnavariatsioon, lause pikkus ja keerukus, teksti formaalsus, leksikaalne ja lausestustihedus, nominaalne ja verbiline stiil
\end{abstract}

Inimese areng on ühtaegu psühholoogia, lingvistika, närvi- ja kasvatusteaduste objekt, kuid isegi mahukas teismeea-arengu ülevaateteoses (Shaffer, Kipp 2014) domineerib koolieelikute kognitiivse ja keelelise arengu kirjeldus - teismeliste kohta käib vaid mõni lõik. Ka süntaksi arengut analüüsitakse harva enam kui 8-9 aasta vanuseni. Emakeele kirjutiste süntaksi arengut koolieas on uurinud nt Cheryl Scott $\left(1988^{1}\right)$, pidades hiljem aru mõõdikute üle. Tema arvates ei sobi koolieelikute mõõtmiseks

Viidatud artiklit ei ole õnnestunud leida, tulemusi vahendatakse Cheryl Scotti ja Sharon Stokesi (1995) järgi. 
mõeldud tööriistad koolieas ega hiljem (Scott, Stokes 1995). Rohkem on tähelepanu pälvinud teise keele kirjutiste areng (nt Malvern jt 2004; Verspoor jt 2012) ning eri laadi suulise kõne süntaks, nt narratiivide ja aineselgituste ealine süntaktiline erinevus (Scott 1988; Nippold jt 2005). Uuritud on ka süntaksikeerukuse keeletüpoloogilist tingitust (nt Berman, Verhoeven 2002), süntaksi terminivaba õpetamise mõju õigekirjale ja teksti mõistmisele (Funke jt 2013) jm. Õpilaskirjutiste arengut algkoolieas on uurinud Anne Uusen (2006).

Kirjaoskuse kooliaegse ja hilisema arengu komplitseeritud olemust kirjeldavad Dorit Ravid ja Liliana Tolchinsky (2002), kes vahendavad ja üldistavad rohkesti arvamusi ja uurimusi, k.a kirjutamise ja kirjutusoskuse kohta. Kõneldes küll palju tekstiliikidest ning süntaksist keele eri vormides ja registrites, seostavad nad praktikat enim õigekirjaoskusega, näidates selle seoseid kõigi väljendus- ja keeletasanditega. ${ }^{2}$ Nende kirjutis määratleb keeleteadlikkust (ingl linguistic literacy), ${ }^{3}$ mille peaks suuresti tagama kool.

Emakeele ega muude keelte oskuse arengut pole võimalik lahutada üksteisest ega koos haridusega kasvavast keeletunnetusest (higher language cognition, Hulstijn 2011). Formaalse hariduse tõttu on läänelik kirjaoskus (vt Rogoff 2003) tugevasti seotud tekstikogemuse kasvuga, mida kool ja kodu suunavad ning mille varal keeleteadlikkus areneb. Ea ja kultuurikogemuse kasvades on nii inimese tekst ise kui ka sellesse kätketud keelendid konstruktsioonina komplekssemad ja mitmekesisemad. (Vt Ravid, Tolchinsky 2002.) Nii on teismeea jm kirjutiste võrdlev uurimine aktuaalne.

Artiklis tutvustame üheksa eesti õppekeelega kooli 5., 7., 9. ja 11. klassi õpilaste kirjutuskatsega kogutud 159 teksti uurimust, mille keskne probleem on õpilase kirjaliku keele areng. (Vt katse kirjeldust allpool.) Arengu taustal ei erista me keele omandamist kui baasstruktuuride loomulikku (universaalse neurobioloogilise mehhanismiga toestatud) järjest komplekssemat assimilatsiooni ning õppimist, mis on vältimatu, kui sihiks on kirjalik keel - lugemine ja kirjutamine nõuavad oskusi, mida tuleb eksplitsiitselt teadvustada. Koos kirjaoskuse õppimisega algab ühtlasi

2 Enne seda on õigekirja enim seostatud fonoloogiateadlikkusega.

3 Termini vaste üle võib vaielda - keelealane kirjaoskus on kohmakas, kuid keeleteadlikkus annab inglise keelde tagasi tõlkides sama ala termini linguistic awareness, mille on kitsama tähendusega, jättes kõrvale žanri- ja stiilitunnetuse. 
morfoloogia ja süntaksi viimistlemine. (Vt Bastos Figueiredo, Silva 2009.) Samas omandavad teismelised koos järeldusoskusega nii abstraktsete sõnade kui ka tervete diskursiivsete üksuste tähendusi (Nippold 2004; Snedker jt 2007). Seetõttu eeldame, et vähemalt emakeele puhul jääb püsima võime kontekste tajudes keelendeid intuitiivselt omandada, mis täiskasvanueaks allub kooli suunatud teadlikkusele keele struktuuridest ja nende kasutustavadest. Õppida kirjutama tähendab alati õppida uut süntaksit, kus luuakse ja organiseeritakse mahukamaid keeleüksusi allutatuna kindlat liiki tekstitervikule. (Ravid, Tolchinsky 2002: 428) Selles raamis on kujundatud meie artiklis kirjeldatav kirjutuskatse ja leiavad oma koha uurimistulemused.

Kirjutised nõudsid kõikides klassides arvamusavaldust sotsiaalsete väärtuste teemal, kahes nooremas klassis seotuna inimese õnnelikkusega ja kahes vanemas hariduse väärtusega. Uuritavat materjali on umbes 30000 sõne mahus.

Katsekirjutiste valimi kirjeldus ja sõnavara puudutavad tulemused on varem avaldatud (Kerge jt 2014). Kirjutiste leksikoni uurides avastasime n-ö arenguseisaku: 5. ja 7. klassi aktiivne sõnavara praktiliselt ei erine (ibid.). Siin vaatame, kas ja kuidas areneb aktiivne süntaks, sest välistatud ei ole näiteks süntaksi kiire arengu pidurdav mõju sõnavarale, milles paneb kahtlema Marilyn Nippoldi jt (2005) uurimuse ilmne paralleel (vt tulemuste juurest).

Uurimus on alustav ja põhilaadilt statistiline, kindlate uuritud parameetrite mõõdikuid tutvustame järgnevas. Statistika annab võimaluse kirjeldada kirjutiste kvalitatiivseid ealisi muutusi ja toetab teoreetilisi arutlusi. Selle toel saab edasiseks süvaanalüüsiks valida kas eatüüpilisi või mingi muutuja poolest äärmuslikke töid - just kvalitatiivanalüüsi materjali argumenteerimine teeb alustava kvantitatiivuurimuse oluliseks. Süvaanalüüsiks on seejuures lugematuid võimalusi, kuid üks artikkel ei mahuta selle tulemusi isegi seal, kus need on juba olemas (nt sidenduse ja tarinditüübistiku areng). Siiski esindavad kvalitatiivset külge allpool toodud näited ja meetodiarutlused.

Võrdluseks on kasutatud peamiselt mittefiloloogidest eesti haritlaste emakeelseid toimetamata kirjutisi, mis on loodud kõrgtaseme ametlikku eksamiolukorda ja loovkirjutuse ülesandeid jäljendades (vt Pajupuu jt 2010). Selle nn esseekorpuse kirjutisi kui haritlasesseid käsitatakse hea keelekasutuse etalonina, mis on õpilase arengu loomulik siht. Täiskasvanu- 
andmete puudumisel on mõnd muutujat õpilastega paralleelselt uuritud esseekorpuse üksiknäiteis, millele siis tekstis ka osutatakse.

Võrdluseks on kasutada ka 2006. aastast praeguseni arendatav žanrikorpus $^{4}$, mis kätkeb suulisi, kirjalikke ja suuliseks esituseks kirjalikult ette valmistatud tekste; spontaanseid ja toimetatud tekste; monolooge ja dialooge jne. Kindla kommunikatiivse tunnusega tekstirühma rööpne uurimine žanrikorpuses lubab iseloomustada ka õpilasi, näiteks rääkida õpilaskirjutiste puhul täiskasvanute suulise või spontaanse keelekasutuse joontest, igasuguste või toimetatud kirjalike tekstide joontest vms (vt nt 28 žanri kommunikatiivsete tunnuste ülevaadet Kerge, Pajupuu 2010: tabel 1). Kui õpilastulemuste võrdlusallikat ei ole osutatud, siis pärinevad andmed eelviidatud artiklist või on arvutatud žanrikorpuse sama osa näitajate alusel.

Allpool kirjeldatakse kirjutuskatset ja tekstimuutujate uurimise meetodeid. Tulemusi esitades diskuteeritakse eri teadusvaldkondade arusaamistega lapse kognitiivsest ja keelelisest arengust.

\section{Kirjutuskatse kujundus}

Kirjutuskatse kujunduse esmatähtis tahk on osaliste valik ja see, milliseid nende kohta kogutud andmeid uurimuses arvestada.

Teismeea piires on kirjutajate valik klasside kaupa oluline seepoolest, et näitab õppekava kui standardi olemasolul enam-vähem ühetaolist keeleteadlikkust ja kirjutuskogemust (Ravid, Tolchinsky 2002). Väikese uurimisressursi puhul tagab klasside kahese intervalliga valim, et osalejate astronoomiline iga rühmades ei kattu - 5. klassis on see 11-12 aastat (valimi keskmine 11,5); 7. klassis 13-14 (keskmine 13,6); 9. klassis 15-16 (keskmine 15,3) ning 11. klassis 17-18 aastat (keskmine 17,3). Osalejate astronoomilise vanuse andmed peaksid teismeea puhul olema vähem olulised kui klassiga määratud kirjakogemus, sest keele n-ö loomulik omandamine oleneb otsesemalt vanusest vaid 11.-12. eluaastani (Bastos Figueiredo, Silva 2009). Ka on mitmed autorid väitnud, et keskmisel tasemel kirjutamiseni jõutakse sõltuvalt alustamise east umbes kümneaastase

4 Loomulike situatiivsete žanrite korpus - hetkel umbes 60 žanri tekstikogumid - on loodud grandi ETF-0050023s09 (Hille Pajupuu) toel; seda on pidevalt täiendatud tänu grandile ETF-8605 (Krista Kerge) ning HTM-i keeleosakonna rahastusele EKKM-i programmi jm lepingutegevustes. 
kogemuse ja praktikaga (Ericsson jt 1993; Lee, Karmiloff-Smith 1996). Allpool opereeritaksegi peamiselt klassi(numbri)ga ning sõnad ,iga” „vanus” „vanuserühm”, „earühm” vms eristavad klasse ja „nooremad”, „vanemad" 5.-7.ja 9.-11. klassipaare, kuid seda põhjusel, et prooviuuringus ei ilmnenud olulist erinevust uuritud muutujate sõltuvusel kirjutaja vanusest aastates ja klassist kui kirjakogemuse üldistajast (kordajate erinevus kadus enamasti sajandiku täpsuseni ümardamisel). Kohati on põhjust rääkida ka õpilaste astronoomilisest east ning võrrelda kirjutuskogemuse ja vanuse mõju muutujale või nende kimbule. Analüüsist jäävad kõrvale võrdselt esindatud Tallinna ja väikeasulate eristus ning kirjutaja sugu.

Katseülesanne pidi eeldama suhteliselt keerukamaid mentaalseid operatsioone ja mitmekesisemaid tarindeid ning aitama vältida jutustavat laadi, mis teeb lihtsaks täiskasvanuteksti (vt Kerge 2002). Ka lapse kirjakogemuse arengut näitavad teksti ilmuvad lingvistilised märgid jutustamisfaasi ületamisest. Näiteks saab hüpoteetiliste argumentide kasutamist mõõta selliste kui-kõrvallausete ilmumisega, mis ei viita selgesti sündmuse toimumise ajale jms. (Scott, Stokes 1995: 309) Sel põhjusel nõudis ülesanne sihipärast arvamusavaldust kõigilt, k.a 5. klassis, kus see pole harjumuspärane (vt ülesandeid allpool). Samas tuli arvestada, et argumenteeriva kirjutamise kulus on enim mõttekorrastuse jm pause, mistõttu teksti pikkus kõigub sama kirjutusaja puhul rohkem kui nt narratiivis (Epting jt 2013: 240).

Järgmine probleem oli, kas kirjutaja peaks lugema mõnd teemaga seostuvat teksti. Kuna kaasnev lugemine on täiskasvanu arvamuskirjutise puhul loomulik, siis kasutati väga üldist häälestavat lugemist 9. ja 11. klassis, kuid mitte noorematel, kelle puhul eelnev lugemine oleks ilmselt päädinud domineeriva ümberjutustusega. Lugemistekst ei puudutanud otseselt ühtki kirjutise võimalikku teemat, vaid väärtuskasvatuse ajalugu.

Katsekujunduse oluline tahk on ka kirjutamiseks antav aeg, mis määrab selle, kas tulemuseks on hästi kavandatud viimistletud tekst või suhteliselt spontaanne loovkirjutis. Kuivõrd 5. klass ei ole kirjutusprotsessi etappe teadlikult õppinud ja viimistlemata hindekirjutised on koolitöö tavaline osa, siis otsustasime viimistlemata kirjutiste kasuks. Sellelaadne materjal näitab hästi eakohast kirjutusvilumust ja lausestruktuuride loomulikku valdamist. ${ }^{5}$ Kirjutusaeg pidi jätma varu teksti ülesandepõhise kavandamise

5 Viimistletud kirjutiste uurimine on lisaks põhikooli lõpueksami ja riigieksami analüüsi osa. 
jaoks, kuid eeldama piisavat pingutust, muutumata samas väsitavaks. Nii anti kirjutamiseks 5. ja 7. klassis üks koolitund ning 9. ja 11. klassis üks astronoomiline tund. Lugemiseks kulunud aega kirjutusaja sisse ei arvestatud.

Katse viisid klassiti läbi õpilaste oma õpetajad. Kirjutati ühetaoliselt kujundatud paberile, mis algas raamistatud ülesandega.

5. ja 7. klassi ülesanne oli sõnastatud järgmiselt.

Kujuta ette järgmist OLUKORDA.

Teie kool tahab korraldada konkursi kõige õnnelikuma ja elus hästi hakkama saava inimese leidmiseks. Kooli ajaleht kogub ja avaldab nüüd võimalikult palju arvamuskirjutisi selle kohta, milline on õnnelik ja elus hästi hakkama saav inimene.

KIRJUTA koolilehele ka oma arvamus: milline inimene on sinu arvates õnnelik ja saab elus hästi hakkama?

Sinu arvamuslugu peaks olema u. 150 sõna pikk ja mahub parasjagu alla kasti - ruumi peaks ülegi jääma. Kirjutamiseks on aega üks koolitund.

9. ja 11. klassil tuli ülesande eel läbi lugeda häälestav üldsõnaline tekst väärtuskasvatuse tähtsusest Eestis eri aegadel (421 sõnet). Ülesanne oli sõnastatud järgmiselt.

Käisid hiljuti

ÕPILASKONVERENTSIL, MILLE TEEMA OLI „VÄÄRTUSKASVATUS”.

Lugesid ka ühe ettekande põhjal kirjutatud teksti. Sinu ülesanne on kirjutada üritusel kuuldust ja loetust artikkel koolilehe jaoks. Lisaks üldisele ülevaatele peatu lähemalt kahel kolmest konverentsil käsitletud teemast.

1. Mis on hariduse peamine eesmärk - kas teadmised või tervikliku isiksuse kasvatamine?

2. Millised iseloomuomadused tagavad õnneliku elu ja ühiskonnas hakkamasaamise?

3. Kas kõik algab kodust või saab kool samuti lapse iseloomuomadusi kujundada?

Teksti nõutav pikkus on umbes 250 sõna. Aega kirjutamiseks on 60 minutit. 
Ülesanded esitati 12 p kirjas. Mõlemal juhul järgnes joonitud ala, kuhu optimaalse pikkusega tekst mahutada.

Veendumaks, et 5. klassiga ühesugune ülesanne ei ole liiga lihtne ning on ka 7. klassi õpilasi ärgitanud loovusele (vrd Kerge jt 2014: 170), lasime pärast sõnavaraanalüüsi kaheksal vilunud emakeeleõpetajal ülesannet analüüsida. Nende kõigi seisukoht oli, et ülesanne on igati eakohane.

\section{Muutujad, nende mõõdikud ja näitajate korrelatsioon eaga}

Kasutasime õpilaskirjutiste süntaksi võrdlemiseks mitmesuguseid mõõdikuid, mis eesti žanriuurimuses kasutatuna lubavad iga uuritava vanuserühma näitaja asetada eesti ühiskeele laiemasse konteksti (vt nt Kerge, Pajupuu 2010) ja toetavad võrdlusi täiskasvanute esseekorpusega, olles samas leidnud rahvusvahelist tunnustust.

Siinkohal ei tutvustata detailselt nende mõõdikute valemeid ega ideoloogiat, mida on eesti žanriuurimuses kirjeldatud, nii et viide lubab asjakohase info veebis hõlpsasti leida. Sellised mõõdikud on järgmised.

- Formaalsusindeks F põhineb sõnaliigisuhetel ja paigutab teksti formaalsuse-kontekstuaalsuse dimensiooni kindlasse punkti (Heylighen, Dewaele 2002; vt Kerge jt 2007). Suurema F-iga tekst on ühemõttelisem, sest nimisõnade kui viitejõulise sõnaliigi suhteliselt suurem määr - eriti kui neid saadavad adjektiivid - aitab teksti vähema kontekstitoega mõista. Formaalsust on kirjeldatud žanriti (vt ka Kerge, Pajupuu 2010; Kerge 2010; Puksand, Kerge 2012).

- Stiiliindeks põhineb substantiivide ja verbide suhtel S : V (vt Puksand, Kerge 2012). Mida suurem on indeks, seda enam domineerib nominaalne stiil verbilise üle, mis hõlbustab sisu jälgimist. Suurem indeks seostub teksti viimistletusega ja kirjalikkusega, väiksem spontaansusega ja enamasti ka suulise vormiga. Maailmas on stiilidominanti indekseeritud verbide ja nimisõnade arvu jagatisena (Malvern jt 2004), mis reastab tekste samal alusel, kuid vastupidi.

- Keerukusindeks Lix (Björnsson 1969; vt Puksand, Kerge 2012) summeerib ümardatult lause keskmise pikkuse, mis on allkeelte keerukuse üks olulisi ennustajaid (vt Kerge 2002), ja seitsme või enama tähega sõnede osatähtsuse, mis osati seostub keerukama morfosüntaksiga (vt allpool). 
- Leksikaalne tihedus LD (Ure 1971; vt Kerge 2010) ehk sisusõnade protsentuaalne osatähtsus kirjutistes kasvab koos õpilaste eaga (Kerge jt 2014: 168). Siin on LD aga oluline hoopis funktsioonisõnade määra kahanemise näitajana. Arenev kirjalik süntaks peaks kaasa tooma uusi funktsioonisõnu (Nippold 2004: 3-4), seega tekib küsimus, kas ja kuidas funktsioonisõnade muutused ilmnevad.

Eelkirjeldatute kõrval kasutame ka kaudsemaid ja otsesemaid süntaksimõõdikuid, mida eesti täiskasvanutekstides uuritud ei ole.

- Sõnavariatsiooni indeks OVIX mõõdab üks kord esinevate sõnede suhet sõnede koguarvuga ega sõltu mõõdikuna teksti pikkusest (Hultman, Westman 1977; Uusen 2006). Oletasime, et eesti keele puhul sobib see (küll väga ligikaudne) mõõdik sõnavormide mitmekesisuse võrdlemiseks. Näiteks kui sõna esineb ühes vormis mitu korda, siis mõjutab see OVIX-i näitajat teisiti kui sõnavara mitmekesisuse mõõdikud (Kerge jt 2014), mis peavad silmas ainult ühe lekseemi eksemplaride arvu, ilma et oleks oluline, kas eksemplarid on kõik ühes või mitmes vormis. OVIX toetub teksti sõnearvule $n$ ja ühekordselt esinevate vormide arvule $N$ ning arvutatakse järgmiselt:

$$
\text { OVIX }=\frac{\log (\mathrm{n})}{\log \left(2-\frac{\log (\mathrm{N})}{\log (\mathrm{n})}\right)}
$$

Idee kontrollimisel ilmnes OVIX-i oluline märgatav seos nimisõnade ja deiktikute osatähtsusega ning nõrk oluline seos verbide, adjektiivide ja asesõnade omaga, kuid ka nõrk negatiivne seos adverbidega, mis kõik on muutuvad või vähemalt vaegmuutelised. Side- ja kaassõnadega puudus OVIX-il korrelatsioon.

- Lausestustihedust (clausal density) mõõdab subordinatsiooniindeks S (subordination index), mis arvutatakse lausungite arvuna ühe nn lõppüksuse ehk T-üksuse kohta (terminal unit). T-üksust defineeritakse kui millist tahes sõltumatut pea- või osalauset koos kõikvõimalike sisestatud lausungitega, arvates T-üksuste hulka nii semantiliselt markeerimata kui ka markeeritud seosega rindosalaused. (Nippold jt 2005: 1061; pikemalt tagapool.) 
Tulemuste enamik sõltus oluliselt kirjutaja east (vt tabel 1; statistiliselt olulised seosed on hallil taustal).

Tabel 1. Uuritud süntaksitunnuste korrelatsioon kirjutaja klassi ja vanusega

\begin{tabular}{|c|c|c|}
\hline \multirow[t]{2}{*}{ Tunnus } & \multicolumn{2}{|c|}{$\begin{array}{c}\text { Pearsoni korrelatsioonikordaja } \\
\text { ja selle olulisus }\end{array}$} \\
\hline & Klass & Vanus \\
\hline Teksti pikkus & $0,588 * * *$ & $0,573 * * *$ \\
\hline Keerukusindeks Lix & $0,730 * * *$ & $0,722 * * *$ \\
\hline - pikad sõnad \% & $0,804 * * *$ & $0,800 * * *$ \\
\hline - lause pikkus sõnedes & $-0,125$ & $-0,135$ \\
\hline Sõnavariatsiooni indeks OVIX & $0,597 * * *$ & $0,567 * * *$ \\
\hline Stiiliindeks S : V & $0,603 * * *$ & $0,567 * * *$ \\
\hline Formaalsusindeks F & $0,586 * * *$ & $0,555 * * *$ \\
\hline Leksikaalne tihedus LD & $0,522 * * *$ & $0,525 * * *$ \\
\hline \multicolumn{3}{|l|}{ Sisusõnad } \\
\hline - adjektiivid & $-0,329 * * *$ & $-0,321 * * *$ \\
\hline - substantiivid & $0,641 * * *$ & $0,614 * * *$ \\
\hline - verbid & $-0,390 * * *$ & $-0,361 * * *$ \\
\hline $\begin{array}{l}\text { - adverbid } \\
\text { Funktsioonisõnad }\end{array}$ & $-0,151$ & $-0,103$ \\
\hline - deiktikud & $-0,540 * * *$ & $0,529 * * *$ \\
\hline • kaassõnad & 0,181 & 0,015 \\
\hline • sidesõnad & 0,056 & 0,143 \\
\hline • hüüdsõnad & $-0,078$ & $-0,081$ \\
\hline
\end{tabular}

Märkus. Seos on arvestatav, kui korrelatsioonikordaja $r>0,3$, ja tugev, kui $r>0,7$. Olulisuse kahesuunaline tõenäosus $p$ on tabelis märgitud järgmiselt: * $p<0,05$; ${ }^{* *} p<0,01 ; * * * p<0,001$.

Tugevasti seostuvad eaga pikkade sõnede osatähtsus ja teksti keerukus, samal ajal kui lause pikkus eaga ei seostu, ehkki Lixi nõrgalt ja oluliselt mõjutab. Kirjutaja vanus mõjutab oluliselt ka sõnavariatsiooni indeksit ning nimisõnamäära ja sellega seotud parameetreid, nagu kirjutiste domineeriv stiil ja formaalsusaste, mis ka omavahel tugevasti ja oluliselt seostuvad. Tulemuste ja diskussiooni kontekstis koondatakse tähelepanu 
nendele muutujatele, mille seos eaga on tugev ja oluline. Muid näitajaid kommenteeritakse teise muutuja mõjurina.

Lausestustihedust, mille aluseks on süntaktiliste seoste laad, on uuritud poolkvalitatiivselt valimi väikses osas (22-s eri vanuserühmade kirjutises; põhjustest allpool), mistõttu teda ei saa suhestada tervikvalimi näitajatega.

\section{Loovate arvamuskirjutiste süntaks}

5. ja 7. klassi kirjutise keskmiseks pikkuseks kujunes 45 min aja puhul 142 sõnet (eeldati 150) ning 9. ja 11. klassis 60 minuti puhul 230 (eeldati 250). Teksti pikkus ei erine 5. ja 7. klassil ega sõltu ei nooremate ega vanemate rühma piires õpilase vanusest aastates.

\subsection{Teksti keerukuse näitajad ja stiil}

Teksti keerukuse ealisi muutusi näitavad nii sõnavariatsiooniindeks OVIX kui ka keerukusindeks Lix oma teguritega (vt tabel 2). Nagu OVIX, nii mõõdab ka pikkade sõnade määr kirjutise suhtelist morfosüntaktilist keerukust. Nende muutujate omavaheline sõltuvus on üsna tugev ja oluline $(r=0,62 * * *)$.

Tabel 2. Uuritud kirjutiste morfosüntaktiline ja tekstikeerukus ning nende tegurid

\begin{tabular}{|l|c|c|c|c|c|c|c|c|}
\hline Vanuserühm & $\begin{array}{c}\text { OVIX } \\
\boldsymbol{c a}\end{array}$ & Std & $\begin{array}{c}\text { Pikki } \\
\mathbf{s o n n u} \\
\mathbf{\%}\end{array}$ & Std & $\begin{array}{c}\text { Lause } \\
\text { keskmine } \\
\text { pikkus }\end{array}$ & Std & Lix & Std \\
\hline 5. kl & 40 & 12 & 21,8 & 4,8 & 15,1 & 5,9 & 37 & 8,1 \\
\hline 7. kl & 40 & 5,9 & 25,2 & 4,9 & 13,1 & 2,6 & 38 & 5,3 \\
\hline 9. kl & 53 & 10,1 & 36,5 & 7,2 & 13,2 & 3,2 & 50 & 7,5 \\
\hline 11. kl & 64 & 9,3 & 42,4 & 5,6 & 13,8 & 2,9 & 56 & 5,6 \\
\hline Täiskasvanud & - & - & 49,3 & - & 14,7 & - & 64 & - \\
\hline
\end{tabular}

Sõnavariatsiooni indeks OVIX kasvab keskmisena alles 9. klassis, kuid on 7. klassis (13-14 a vanuses) vähem hajus kui 5. klassis; vt joonis 1. 


\section{OVIX}

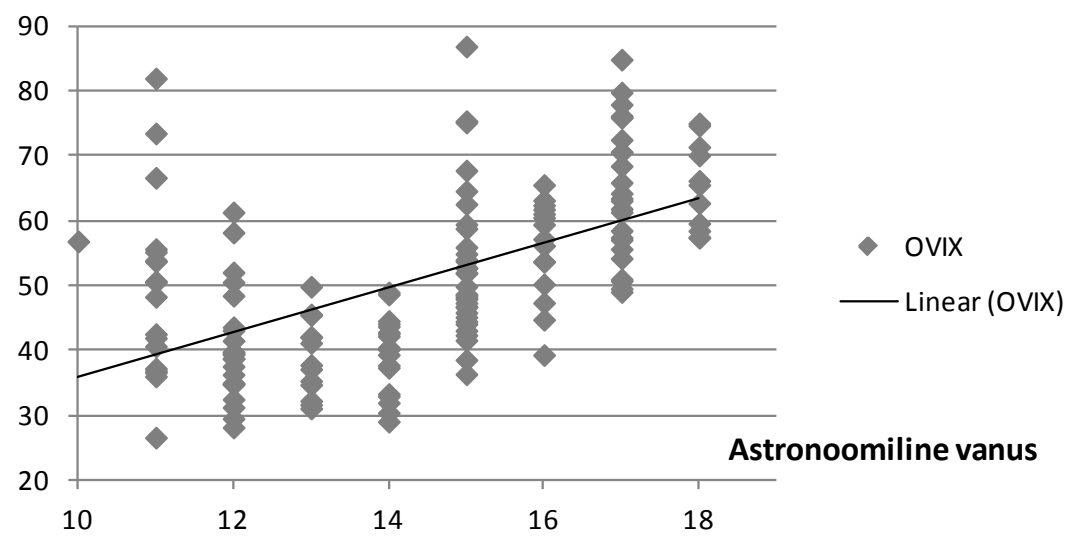

Joonis 1. Kirjutiste sõnavariatsiooni indeksi näitajad õpilase vanuse järgi

OVIX kui vormirohkuse väga suhteline näitaja suunab edasist kvalitatiivset uurimist. Näiteks on võimalik tekstiti võrrelda kindla sõnaliigi morfosüntaktilist varieeruvust, mida siin demonstreeritakse kahe - klassi mediaanväärtuses OVIX-iga - töö alguslõigu verbide varal; näited 1 ja 2. Keelendite varieeruvust uuritavas materjalis saab mõõta Guiraud' indeksiga $G$, mille valem $G=N: \sqrt{ } n$ arvestab eri keelendiliikide arvu $N$ ja sama liiki keelendi esinemisjuhtude arvu $n$. Kuigi valemit on kasutatud ainult üldise leksikaalse varieeruvuse mõõtmiseks, saab seda kohandada ühe sõnaliigi leksikaalse või morfosüntaktilise varieeruvuse mõõtmiseks, nt võtta leksikaalse varieeruvuse arvutuses üksuseks $N$ uuritava tekstimassiivi eri verbide arvu ning morfosüntaktilise varieeruvuse arvutuses eri verbivormide arvu; mõlemal juhul on $n$ verbisõnede arv. Võrdlevalt saab kirjeldada leitud väärtuste sisu ja kõikumist.

(1) Ühiskonnas hakkama saamiseks on vaja positiivset suhtumist ning teistega arvestamise oskust. Teistega arvestamist on vaja koolis. Seal ei

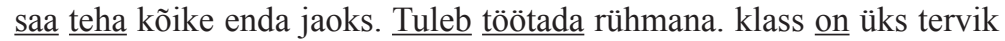
ja kõik mõjutavad kõiki. Kodus on sinu enda perekond ja muidugi sa hoolid rohkem neist ja te hoiate rohkem $\underline{\text { uhtel }}$. (9. $\mathrm{kl}$ )

(2) Minu arvates on kõige õnnelikum ja elus hästi hakkama saav inimene see kes on Töökas ja rõõmsameelne. Kindlasti peab rõõmsal inimesel või siis kasvõi õpilasel kindel elukoht kus on kõik korras, Töökoht kus on kindel 
palk ja perekond kes on ise rõõmsad ja kelle parast ei pea muretsema, just need kolm asja teevad inimese peamiselt õnnelikuks. (7. $\mathrm{kl}$ )

Näites 1 on 9 eri verbi (sh ühend- ja väljendverbid, leksikaalsed ja abiverbid) 11 eksemplaris, mis esinevad kokku 6-s ainsuse või mitmuse vormis, kuvades olukordi dünaamiliselt modaalsena nii lause öeldises (on vaja) kui ka selle osas (ei saa teha, tuleb töötada) või vastandades suhteid ning olukordi kodus ja koolis (mõjutavad, on), k.a üldistavas ainsuse ja mitmuse II isikus (hoolid, hoiate ühte). Lõigu verbide leksikaalse varieeruvuse indeks on 2,71, morfosüntaktilisel varieeruvusel aga 2,11 . Näites 2 on 5 verbi 9 eksemplaris, mis esinevad 5 vormis allutatuna avalauses kõneleja häält osutavale kaassõnafraasile minu arvates. Esineb samasugust dünaamilist modaalsust (peab [olema], ei pea muretsema), kuid domineerib jaatava kindla kõneviisi üldoleviku III isik (on, teevad), kuna $m a$-tegevusnimi on kesksõnalise täiendina kasutatud väljendverbi ja teisal perifrastilise öeldise osa (hakkama saav, ei pea muretsema). Nii lõigu verbide leksikaalne kui ka morfosüntaktiline varieeruvus on 1,67. Nii võib sõnaliigisuhete kõrval kirjeldada iga sõnaliigi varieeruvust tekstis või korpuses ja võrrelda tekstikogumite näitajaid omavahel. ${ }^{6}$

Tekstikeerukuse indeksiga Lix mõõtsime võrdlevalt õpilaskirjutisi ja täiskasvanute esseekorpust (tabel 2).

Kirjutiste kvalitatiivses võrdluses ilmneb pikkade sõnade ja komplitseerituma morfosüntaksi seos mitme tunnusega sõnavormide, tuletiste ja liitsõnade enama kasutuse või moodustamise näol (näiteis 3-5 on pikad sõnad ühekordselt alla joonitud). Kõige ,pikasõnalisemas” kirjutises (11. klass) näeb teine lõik välja nii.

(3) Haridus ei tähenda pelgalt koolitundides omandatud raamatuteadmisi. Palju tähtsamat rolli mängib kool iga õpilase individistliku mentaliteedi kujundamisel. Kooliteekonnal peaksid õpetajad olema suutelised õpetada ka töökust, hoolivust eakaaslaste suhtes ning eelkõige vastutustunnet. Kõik eelnevalt nimetatu on vajalik selleks, et hiljem iseseisvas elus tuleks iga üks endaga ise toime. Väärtuskasvatus ei tohiks kindlasti vabadust hakata piirama, vaid hoopis peaks kujundama välja tervikliku isiksuse, kes on oma elu peremees. (Lõigu keskmine lausepikkus on 13,2 sõnet; pikki sõnu 47\%.)

${ }^{6}$ Oleme praeguseks meetodit edukalt katsetanud kaassõnade ning sidesõnade ja siduvate funktsioonisõnade võrdlemiseks earühmiti, k.a täiskasvanud (esseekorpuse näited). 
Valimi „lühisõnalisim” kirjutis (näide 4) ja sellest ligi kaks korda suurema pikkade sõnade määraga töö (näide 5) - mõlemad 5. klassi terviktekstid näitavad eelneva taustal, kuidas pikkade sõnade osatähtsus eaga seostub. Näide 4 on lihtsakoeline nii süntaksilt kui ka sõnavaralt; näite 5 süntaks on mitmekesine, kuid pikkade sõnade suurema osatähtsuse taga on kordused ja kahel juhul ka kirjavead. ${ }^{7}$

(4) Elas kord poiss kelle nimi on prints Julius Šimoon. Julius läks üks kord oma sõbra juurde. Kui ta sõppra nägi küsis Julius. Miks sa nii õnnelik oled? Sõber vastas, et ta leidis oma pereknna ülese. Julius mõtles, et miks mina oma perekonna üle ei rõõmusta? Julius otsustas, et kutsub isa õhtul enda tuppa. See oleks juba õnnestunud kuid siis helises isa telefon ja ta läks. Julius jäi magama. Kui ta hommikul ärkas, siis läks ta kohe küla poodi asju ostma, siis jõudis ta koju ja pani asjad kokku, läks aeg mööda ja oli öö. Tema oli üleval, oli vaikus. Ta ronis mööda redelit Julius oli unine ja kohe nii unine, et jäi tee serva magama. Koristaja leidis ta ja viis magama. Kui prints ülese ärkas, oli isa Juliuse juures ja küsis: „miks sa öö õues veetis?” Julius ütles, neil on emaga es tähtis töö. Isa sai aru ja võttis terve kuu vabaks lõpuks leidis julius enda (Teksti keskmine lausepikkus on 9,8 sõnet; pikki sõnu 7,7\%.)

(5) Õnnelik inimene on see kelł ei ole mingeid probleeme. Näiteks tal on hea pere ilus kodu hea töökoht ja head lapsed. Kui lastel läheb koolis hästi siis saavad lastest head töölised nagu ta isa. Ja kui isal on hea töökoht, pole mingeid raha probleeme. Ja pole siis mingeid pereprbleeme. Ja kui

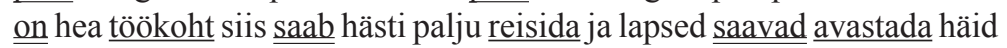
paiku, kus tulevikus koos perega tulla ja lõbusalt aega veeta. Ja kui on hea naine, kes alati kodus süüa teeb siis on lastel hea peale kooli koju

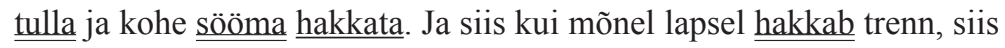

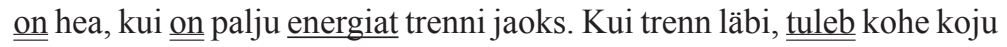
õppima ja pole mingeid probleeme õppimisega. Ja kui kodus õppitud ja kui vaba aega on, siis kas läheb õue või on toas vaatab telekat. Ja kui on juba õhtu lähevad kõik magama, et hommikul reipalt hommikud alustada. Ja koolis jälle häid hindeid saada. (Teksti keskmine lausepikkus on 13,4 sõnet; pikki sõnu 18,6\%. Topeltjoon osutab verbitarinditele ja aitab märgata nii lause põhitüüpe, mille seas on isegi tulemuslause, kui ka lausungitüüpe.)

Näited 4 ja 5 on eripärased - esimene on valimi ainuke jutustus; teine on 5. klassi parimate süntaksinäitajatega töö hoolimata eakohastest kirjavigadest, sisekõne laadis sidumisest (12 lausest algab $8 \mathrm{ja}$ 'ga) ja hindest kolm, mida võis mõjutada ka earühma keskmiste varieeruvusnäitajatega sõnavara (vt Kerge jt 2014). 
Pikkade sõnade 5. ja 11. klassi individuaalsete äärmusväärtuste käärid valimis - $8 \%$ versus $56 \%$ - ja nende keskmäära erinevus klassiti ei luba kahelda, kas pikkade sõnade osatähtsus eesti vormirikkas keeles kedagi või midagi eristab (vrd Puksand, Kerge 2012). 5. ja 11. klass erinevad nende määralt umbes kaks korda; 11. klassi näitaja on 9. klassi omast samavõrra ees kui täiskasvanute esseekorpuse keskmisest maas. (Vt ülal tabel 2.)

Lause pikkus ei sõltu kirjutaja vanusest ja Lix omakorda sõltub vähe lause pikkusest ( $r=0,28^{* * *}$, determinatsioonikordaja $\left.d=0,08^{8}\right)$. Kvalitatiivne erinevus on siiski ilmne: 5 . klassi keskmine lause on teistest earühmadest kuni 2 sõnet pikem ja kohati suulisepäraselt pikk (vt arutlust lausestustiheduse kontekstis), teisalt võib aga 12-aastase tekst olla hakitud suhteliselt lihtsateks lauseteks (vt ülal näide 3). 5. klassi lause kõigub pikkuselt enim: standardhälve on seal umbes 6 sõnet, muudes klassides aga 2-3 sõnet.

Lix sõltub oluliselt ka teksti pikkusest, kuid nende vastastikmõju on suhteliselt väike $(r=0,34)$ ega kalluta tulemusi. Suurim keerukusnäitaja valimis on 70 (11. klass; vt näide 1), s.o suurem kui keskmine teadustekstide keerukuse indeks 62 (Puksand, Kerge 2012: 179). Lixi hajuvusest annab pildi joonis 1, kus aluseks on detailsemana laste iga, ehkki selle mõju Lixile on klassiga ühesugune ( $d$ vastavalt 0,52 ja 0,53$)$.

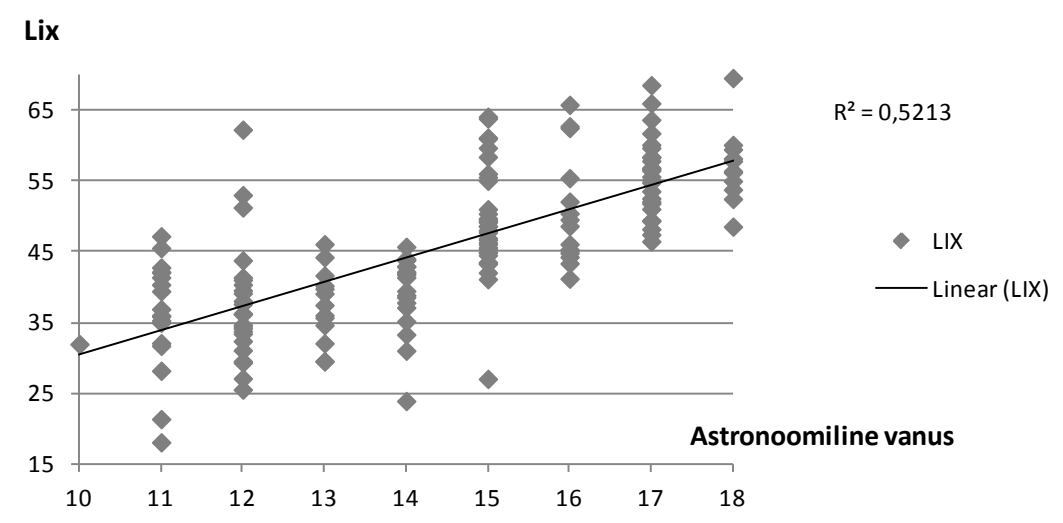

Joonis 2. Kirjutiste keerukus ehk Lixi väärtused kirjutaja vanuse järgi

${ }^{8}$ Katrin Niglase järgi (vt „Statistika loengumaterjale”. TPÜ, 1997: 54-55) võib determinatsioonikordajat käsitada mõju ligikaudse protsentuaalse osatähtsusena, mis siin on siis u $8 \%$. 
Nominaalne stiil, mis liialdusse ei kaldu, iseloomustab sisutäpsust ja konteksti sobivat tihedust, sest nimisõnad kannavad teemat (Halliday 1994: 352), ja toetab sidusust, sest nimisõnad seovad nii teksti osi kui ka teksti kontekstiga (Baratta 2010), andes (all)tähenduse nii adjektiividele kui ka verbidele. Samas aitab just verbiline stiil teksti paremini jälgida (Kasik 1995). Žanrikorpuses seostub verbilisem stiil oluliselt suulisuse ja spontaansusega. Kirjalike žanrite keskmine stiiliindeks on u 1,9, suulise dialoogi oma 1,1 (Puksand, Kerge 2012: 184 jm).

Õpilaskirjutiste stiiliindeks püsib 5. ja 7. klassis 0,8 juures, nagu see on haritlaste läbirääkimisdialoogis ja teismeliste meilides. Indeks kasvab hüppeliselt 1,3-le põhikooli lõpus ega suurene enam oluliselt (11. klassis 1,4), olles lähedal haritlasesseede 1,5-le. Individuaalselt suurim stiiliindeks 2,64 sarnaneb asjaliku toimetatud teksti omaga ( $\mathrm{ibid}$.). Töö osutuski valimi ainsaks ühega hinnatud ja teemakaugeks lugemisteksti ümberkirjutuseks näite 6 autor on 9. klassi muu emakeelega poiss, kes võis kompenseerida oskuste puudujääke. ${ }^{9}$

(6) Eesti koolitraditsioon on väga vana ja haridus on aeg-ajalt kõrgelt väärtustatud. Eesti esimene pedagoogiprofessor, iseseisva Eesti esimene haridusminister ja meie rahvusülikooli rajaja Peeter Põld pidas kõlbelist kasvatust kogu kasvatuse teljeks. Artiklis „Kultura ja rahvushariduse korraldus” (1911) tõi ta välja hariduse ja väärtuse seose. „Haridus on kasvatuse läbi omandatud kultura. Mida tõeliselt hariduseks ja keda haritud inimeseks pidada, see oleneb meie kultura, väärtuste, hundament. Kultura edasikestmise seisukohalt tuleb hariduse panust (?) üles seades väärtusi otsida, mis vähem aegade ja olude muutmisest olenevad, selle vastu, aga oludele ise kuju suudavad anda ja uusi väärtusi luua."

Peeter Põlluga saab vaid nõustuda - hariduse aluseks on meie arusaam sellest, millist inimest me tahame kasvatada. Kuni nõukogude okupatsioonini peeti õpilastele kõlbelist kasvatust töökuse, aususe, hoolivuse, vastutustunde jpm kasvatamist - üheks kooli olulisemaks ulesandeks.

Stiiliindeksit mõjutab suuresti nimisõnamäär $(d=0,89)$, kuid nende muutujate väärtused ei kasva ühtviisi (vt joonis 3).

9 Seegi viitab süvaanalüüsi vajadusele, mis Eestis üha sagedamini jääb nii inimeste kui ka rahapuuduse taha. 


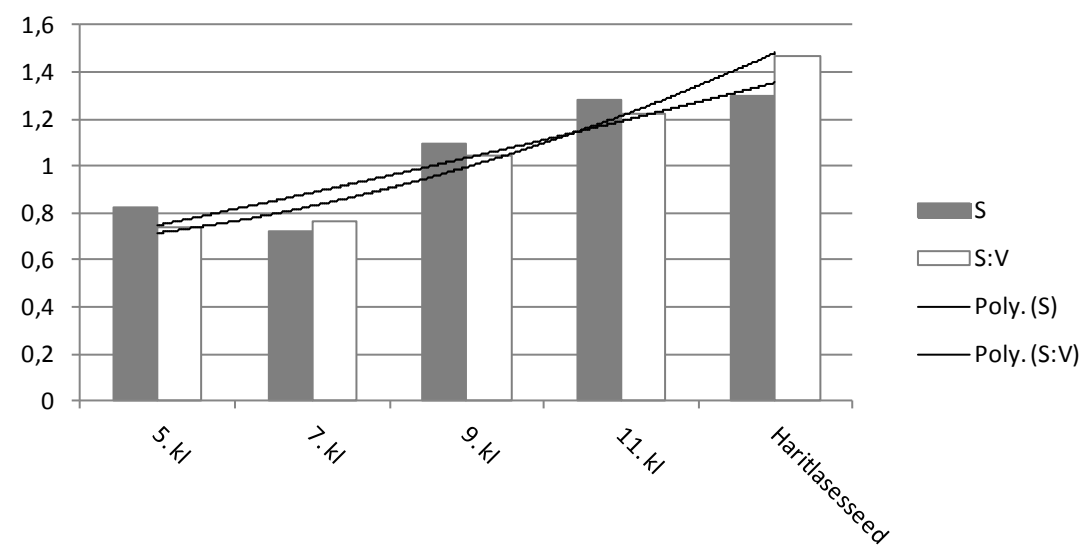

Joonis 3. Nimisõnamäära ja stiiliindeksi muutumise kõrvutav ülevaade klassiti

Iseloomulik on nimisõnamäära ebaoluline (ilmselt juhuslik) vähenemine 7. klassis, samal ajal kui stiiliindeks nihkub ebaoluliselt, kuid ühtlasemini kirjalikule iseloomulikus suunas. ${ }^{10}$

\subsection{Teksti formaalsus ja tihedus}

Formaalsusindeks põhineb kõigil sõnaliikidel ${ }^{11}$. Selle väärtused näitavad, et vanusega paranevad oluliselt õpilaskirjutiste ühemõttelisus ja väljendustäpsus. Ehkki formaalsust suurendavad nimisõnad, adjektiivid ja kaassõnad, mõjutavad F-i enim nimisõnad $(d=0,83)$, mis teevad teksti järjest mõiste- ja viitetihedamaks (Kerge 2010). Õpilaste formaalsusindeksile on eriomane kaassõnade olematu mõju $(d=0,002)$; eesti žanrikorpuses ja esseekorpuses on nende mõju väga tugev ja oluline. Adjektiivid, mida on noorematel enam kui vanematel, ei mõjuta formaalsust ei siin ega eesti tekstis üldiseltki.

Otseseid tihedusmõõdikuid on kahte sorti: leksikaalsed ja süntaktilised.

Funktsioonisõnade määra kahanemine kaasneb kirjutiste leksikaalse tiheduse pideva ja olulise kasvuga (vt viimase kohta Kerge jt 2014). See

\footnotetext{
${ }^{10}$ Polünoomi mõistet (jn 3 trendijooned) vt otsinguga, nt http://et.wikipedia.org/wiki/ Pol\%C3\%BCnoom.

${ }^{11}$ Sõnaliikide määramise kohta žanrikorpuses vt Kerge jt 2007: 631.
} 
kahanemine toimub õpilastel aga ainult deiktikute kui kombineeritud sõnaliigi, s.o asesõnade ja asemäärsõnade arvelt $(d=0,77)$, mis žanrikorpuses tugevasti seostuvad suulisusega. Kaassõnade 1,6\% määrgi on õpilaskirjutistes suulisepärane haritlasesseede $2,5 \%$ vastu. Ka sidesõnade $8,9 \%$ määr on kõige lähemal suulisele tekstile $(9 \%)$, kuna haritlasesseede $8,4 \%$ viitab enam spontaansusele $(8,1 \%)$.

Teksti lausestustiheduse mõõdik, subordinatsiooniindeks $\mathrm{S}$ väljendab lausungite arvu nn lõppüksuse ehk T-üksuse kohta. T-üksust defineeritakse kui millist tahes sõltumatut pea- või osalauset koos kõikvõimalike sisestatud lausungitega. (Nippold jt 2005: 1049, näited samas 1061) Probleemideta T-üksuste määramine ei ole; ${ }^{12}$ näiteks on probleemne vaid-osalausete sõltumatus, samuti eesti keelele tüüpilised aluseta rindosalause juhud, kuid kõik need osalaused loeti siin sõltumatuks. Rindosalauseks ei loetud siin samasubjektiliste öeldistäidete (Inimene on ilus ja õnnelik) ega muid koondlausejuhte. Alistatud üksuseks arvestasime n-ö väljaarendatud lauselühendid, milles verbil oli vähemalt üks laiend ja puudus vormi kaassõnastumise kahtlus (nt Õnnelik olles/ on teised ka õnnelikud, aga mitte minu arvates või alates Tallinnast ja lõpetades Võruga).

Cheryl Scotti 30 osalisega pikiuurimuses (1988, tsiteeritud Nippoldi jt 2005 järgi) on S-indeks 3., 5., 8. ja 11. klassis pidevalt kasvanud (keskväärtused 1,22 > 1,29>1,39>1,52). Muutuja on Nippoldi jt enda (2005: 1055) suulise teksti uurimuse järgi žanrisõltlik, kuid näitab õpilastel olenemata žanrist ootamatut kahanemist 13 aasta vanuses.

Arvutasime selle näitaja katseliselt 22 kirjutises (maht u 4200 sõnet). ${ }^{13}$ Ilmestavaks võrdluseks analüüsisime täiskasvanud haritlaste korpusest ühte juhuslikku mittefiloloogi toimetamata esseed. Ülevaate tulemustest annab tabel 3.

${ }^{12}$ T-üksuste ebamäärasuse tõttu on näiteks nelja keele üliõpilasnarratiivide süntaksikeerukuse võrdluses (Nir, Berman 2010) kasutatud täpsustatud metoodikat, kus rinnastust vaadatakse teksti sisulise kulu aspektist hierarhilisena, kuid siin ei olnud piisavalt lingviste, kes oleks pädevad tegema samalaadset kvalitatiivset eelmärgendust - metoodika nõuab mitme inimese märgenduse (st üksuste funktsionaalse tõlgenduse) $90-95 \%$ kattuvust.

${ }^{13}$ Valik lähtus nii valimiosa keskhinde lähedusest earühma keskmisele sugude ja klasside kaupa kui ka ühesuguse ülesande ja kirjutusajaga valimiosade mahu võrreldavusest. 
Tabel 3. Kvalitatiivselt uuritud kirjutiste lauseparameetrite võrdlus klassiti

\begin{tabular}{|l|c|c|c|c|c|}
\hline Vanuserühm & Lauseid & $\begin{array}{c}\text { Lause } \\
\text { pikkus }\end{array}$ & T-üksusi & $\begin{array}{c}\text { Osa- } \\
\text { lauseid }\end{array}$ & $\begin{array}{c}\text { Lausestus- } \\
\text { tihedus S }\end{array}$ \\
\hline $5 . \mathrm{kl}$ & 8,4 & 18,0 & 15,6 & 29,2 & 1,87 \\
\hline 7. kl & 11,5 & 12,9 & 17 & 29,7 & 1,73 \\
\hline 9. kl & 16,7 & 13,0 & 20,3 & 34 & 1,67 \\
\hline 11. kl & 16,6 & 17,9 & 22 & 39,2 & 1,78 \\
\hline Täiskasvanud & 20 & 10,55 & 20 & 42 & 2,1 \\
\hline
\end{tabular}

S ei sõltu teksti pikkusest $(r=-0,09)$, kuid on keskmiselt tugevasti seotud lause pikkusega (mis võib olla juhuslik).

Kuivõrd lause pikkus ei sõltunud east üldse, siis oli sama mõneti ootuspärane ka lausestustiheduse puhul. Väikses katsevalimis erineb lausestuse individuaalne tihedus õpilasiti 7. klassis kuni 1,6 korda ning kolmes muus uuritud rühmas kuni 1,9 korda. Tulemused viitavad sellele, et mõõdik töötabki ilmselt individuaalse arengu näitajana ehk vajaks ühe ja sama kontingendi pikiuurimust (Scotti eelviidatud tulemused peegeldavad ühtede ja samade õpilaste arengut).

Lausestustiheduse ulatuslikud mõõtmised sundis kõrvale jätma ka uuritud kirjutiste S-näitaja suhe tekstisüntaksi kvaliteediga ehk küsimus, millest tulemus räägib. Toodagu näiteks kaks tiheda lausestusega kirjutist. Võrdluses ilmneb selgesti, et olenemata õigekirjaraskustest võib 5. klassi tekst (näide 7) kajastada teemat mitmest aspektist ja lihtne süntaks olla suhteliselt ladus (paitsi allpool kirjeldatav suulisepärasus) ning 11. klassi töö (näide 8) olenemata komplitseeritumast teemakäsitlusest ja earühma keskmist ületavast lausestustihedusest olla kohati nigela, aga mitte näitest 7 viletsama süntaksiga.

(7) Minu arvates on õnnelik inimene see/ kellel on kõht täis, soe kodu/ ja kõik pereliikmed kodus,/ sellepärast et, ta saab oma rõõmu teistega jagada/. Kui sa oled rõõmus,/ siis, ära hoia seda tagasi/ vaid jaga seda./ Õnnelik olles/ on teised ka õnnelikud,/ kui sina oled õnnelik,/ siis on su klassi õed, vennad, ema, isa, õde, vend ning su vanaema ja vanaisa./ Õnnelik oled siis,/ kui teised on rõõmsad./ Alati on tore midagi teha/ N: olla sõpradega,/ käia kinos,/ olla oma perega./ Iga inimene on elus õnnelik, kas või ühe korra./ Kui oled õnnelik/ siis on sul elus vedanud,/ sest; mõned inimesed ei võimalda endale rõõmu./ Kui sul on hea süda,/ siis austa teisi inimesi/ ja ole sõbralik,/ siis on teine inimene õnnelik./ Kui perre sünnib uus 
pereliige,/ siis oled ka õnnelik/ või kui sa abiellud,/ siis oled ka õnnelik/ sünnipäeval oled ka õnnelik./ (5. kl; lauses 16 sõnet; $S=2,5$ )

(8) Eelmisel nädalal käisin õpilaskonverentsil/ mille teema oli „Väärtuskasvatus"./ Konverentsil oli kohal esindajaid kõikidest koolidest üle Eesti, alates Tallinnast ja lõpetades Võruga./ Arutleti teemadel,/ mis on väga argipäevased,/ ning ühest neist teemadest oli selline:/ Mis on hariduse peamine eesmärk - kas teadmised või tervikliku isiksuse kasvatamine?/

Tänapäevases Eestis on hariduse peamine eesmärk/ saavutada meie riigi majanduslik jõukus ja edu,/ millega ei pöörata tähelepanu meie vaimsele arengule./ Enne nõukogude okupatsiooni olid meie kooli peamisteks ülesanneteks /õpetada õpilastele töökust, ausust, hoolivust, vastutustunnet,/ sest seda peeti siis kõlbeliseks kasvatuseks, / kuid nõukogude okupatsioon hävitas sellised kasvatusviisid./ Selle tõttu ongi meie ühiskondlik elu laostunud/ ja korruptsioon leiab peaaegu igas linnas/ kellel on vähegi oskust seda näha./ See toobki mind järgmise käsitletud teema juurde,/milleks oli:/ Millised iseloomuomadused tagavad õnneliku elu ja ühiskonnas hakkamasaamise?/

Tänapäevases Eestis on vajalikud iseloomuomadused õnnelikuks eluks sallivus ja individuaalne valikuvabadus,/ kuid see ei lähe kokku teiste ühiskonna normidega,/ sest need on ka taunitavad./ Ühiskonnas hakkamasaamiseks on tähtis jällegi majandamise oskused,/ sest ilma nendeta ei saa koolis omandatud hariduse abil saadud palka mõistlikult kulutada/ ja kui palju tuleks säästa /ning see viib mind konverentsil olnud viimase teema juurde,/ milleks oli:/ Kas kõik algab kodust või saab kool samuti lapse iseloomuomadusi kujundada?/ Sellele küsimusele vastates/ saime teada,/ et kool on samuti võimeline kujundama lapse iseloomuomadusi,/ kuid kodu on see/ mis määrab iga viimase kui õpilase iseloomu ja tahte koolis õppida ja pingutada./ (11. kl; 25,4 sõnet lauses; $S=2)$

S-valimis on 5. ja 11. klassi keskmine lause ühtviisi 18 sõnet pikk (erinedes 11. klassi tervikvalimi keskmisest 13,8), kuid teksti- ja lauseehitus ei ole võrreldav. Ehkki näide 7 seda ei ilmesta, kirjutab 5. klass ka katsevalimis pikkade suulisepäraste lausetega, oskamata veel liigendada mõttevoolu või sisekõnet selgepiirilisteks lauseteks ega teksti lõikudeks. Arvamuskirjutise jm teksti komponeerimist ei ole veel õpitud ning kirjutatakse lineaarselt üles pähetulevaid mõtteid ja näiteid. 11. klassis on tekst märksa selgemini komponeeritud hoolimata sellest, et 60 min katse ei jätnud aega viimistluseks. ${ }^{14}$

${ }^{14}$ Seda näitab ka paralleelselt uuritud sidendus, kuid need tulemused on publitseerimata ega mahu siia artiklisse. 


\subsection{Süntaksimuutuste üldpilt, järeldused ja diskussioon}

Et süntaksimuutjate ealist arengut üldistada, teisendasime võrreldavaks need individuaalsed näitajad, mis tugevasti sõltuvad kirjutaja east (tabel 1), ja liitsime tulemused nn koondindeksiks. Indeks summeerib järgmised valimi mediaani suhtes 10-le keskmistatud näitajad: formaalsus, pikkade sõnade määr, keerukusindeks Lix, viitetihedus (nimisõnamäär), deiktikute määr (negatiivsena), sõnavariatsiooni indeks OVIX ja stiiliindeks S : V. Kõrvale jäid individuaalselt kõikuv lausepikkus ja ea suhtes ükskõiksed sõnaliigid. Individuaalsetele indeksitele toetuvad tulemused on üldistatud joonisel 1.

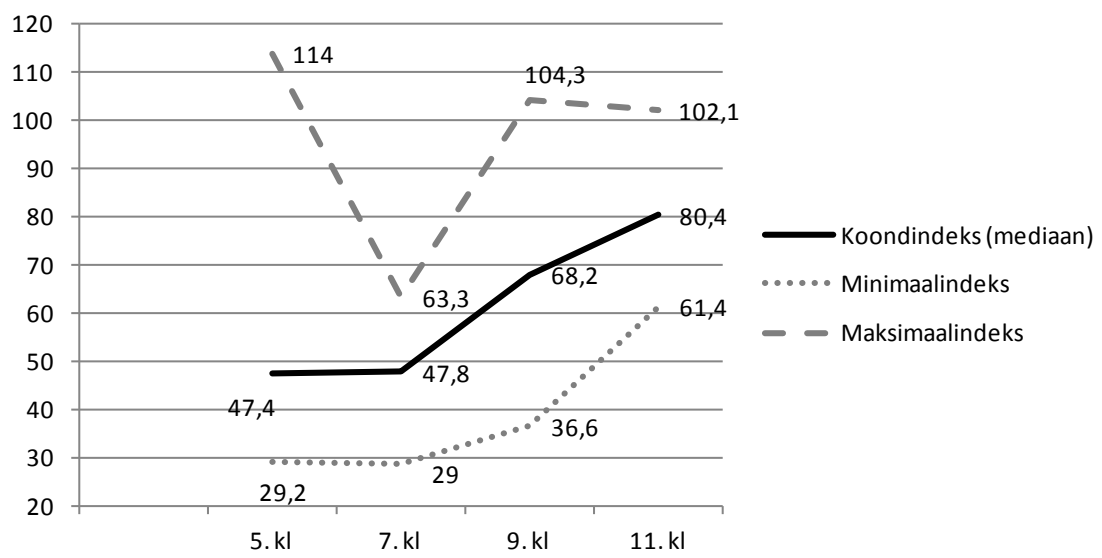

Joonis 4. Süntaksiarengu koond-, minimaal- ja maksimaalindeks klassiti

Üldjoontes on süntaksiarengu leitud kõver sarnane kirjutamise tehnilise vilumuse, s.o käe- ja silmaliigutuste koordinatsiooni arengu kõveraga (Alamargot jt 2010) ning Nippoldi jt (2005) suulise süntaksi arengu kõveraga (vt allpool). Sisu haldamine nõuab kirjutajalt nii tähelepanu eemaldumist kirjutamistehnikalt (käelise protsessi automatiseerumist) kui ka võimet keskenduda võimalikele strateegiatele ja oskust kirjutist kavandada, mis mõlemad vajavad õpetamist (Deal jt 2009: 9-10) - nõrgimate kirjutajate võimekuse ühtlast kasvu on selgelt näha. Joonis 4 näitab, et süntaksi minimaalindeks kasvab pärast 7. klassi suhteliselt ühtlaselt, mis lubab oletada nii kirjutuskogemuse ja keeleteadlikkuse kasvu kui ka õpetamise tähtsust. Maksimaalnäitajate pilt on seevastu juhuslik - kas lugeda siit 
välja keeleandekuse, kasvukeskkonna, lugemuse vm individuaalset mõju, selle üle ei ole võimalik isegi spekuleerida.

Süntaksiarengu indeks korreleerub tervikvalimis võrdlemisi tugevasti ja oluliselt nii kirjutuskogemusele viitava klassi kui ka õpilase vanusega. Kõigi nimetatud muutujate vastastikmõju kõigub rühmiti (vt tabel 4). 5. klassi individuaalsed koondindeksid paiknevad hajusalt; tugevaim süntaksiarengu sõltuvus klassist ja astronoomilisest east ilmneb seda vanuserühma kõrvale jättes (vt 7.-11. klassi tulemusi). 5.-7. klassi rühmas ei sõltu koondindeks kirjutuskogemusest ja selle nõrk seos lapse vanusegagi on ebaoluline. 7.-9. klassi rühmas sõltub süntaksiindeks kõige selgemini õpilaste kirjutuskogemusest (mõju indeksile $d$ järgi u 40\%) ja veidi vähem vanusest (mõju u 30\%). Sõltuvus klassist ja vanusest säilib olulisena 9.-11. kl rühmas, ehkki on siin veidi nõrgem.

Kontrollisime ka süntaksi koondindeksi ning sõnavara mitmekesisuse näitajate (Kerge jt 2014) vastastikmõju - see on nii üldise kui ka keerukama sõnavara osas keskmiselt tugev, kuid puudub täiesti nii noorema kui ka vanema kirjutajarühma sees. Võrdlemisi selgesti eristab seos süntaksi ja sõnavara mitmekesisuse mõlema näitaja vahel 7. ja 9 klassi. (Vt tabel 4.)

Tabel 4. Süntaksiarengu indeksi seos klassi ja kirjutaja vanuse ning sõnavara mitmekesisusega

\begin{tabular}{|l|c|c|c|c|c|c|c|c|}
\hline & \multicolumn{3}{|c|}{$\begin{array}{c}\text { Süntaksiindeksi sõltuvus } \\
\text { earühmast }\end{array}$} & \multicolumn{3}{c|}{$\begin{array}{c}\text { Süntaksiindeksi sõltuvus } \\
\text { sõnavara mitmekesisusest }\end{array}$} \\
\hline \multirow{2}{*}{$\begin{array}{c}\text { Muutuja } \\
\text { Rühm } \downarrow\end{array}$} & \multicolumn{2}{|c|}{ Klass } & \multicolumn{2}{c|}{ Vanus } & \multicolumn{2}{c|}{$\begin{array}{c}\text { Sõnavara } \\
\text { üldine } \\
\text { varieeruvus }\end{array}$} & \multicolumn{2}{c|}{$\begin{array}{c}\text { Harvema } \\
\text { sõnavara } \\
\text { varieeruvus }\end{array}$} \\
\cline { 2 - 9 } & $r$ & $d$ & $r$ & $d$ & $r$ & $d$ & $r$ & $\mathrm{~d}$ \\
\hline Kogu valim & $0,63 * * *$ & 0,40 & $0,60 * * *$ & 0,36 & $0,50 * * *$ & 0,25 & $0,50 * * *$ & 0,25 \\
\hline 7.-11. kl & $0,71 * * *$ & 0,50 & $0,68 * * *$ & 0,46 & $0,49 * * *$ & 0,24 & $0,48 * * *$ & 0,23 \\
\hline 5.-7. kl & $-0,14$ & 0,02 & $-0,21$ & 0,04 & 0,04 & 0,16 & $-0,11$ & 0,01 \\
\hline 7.-9. kl & $0,64 * * *$ & 0,41 & $0,56 * * *$ & 0,31 & $0,42 * * *$ & 0,18 & $0,40 * * *$ & 0,16 \\
\hline 9.-11.kl & $0,44 * * *$ & 0,19 & $0,38 * * *$ & 0,14 & 0,02 & 0,00 & 0,10 & 0,01 \\
\hline
\end{tabular}

Märkus. Seos on arvestatav, kui korrelatsioonikordaja $r>0,3$, ja tugev, kui $r>0,7$. $d$ on determinatsioonikordaja. Olulisuse kahesuunaline tõenäosus $p$ on tabelis märgitud järgmiselt: ${ }^{*} p<, 05 ;{ }^{*} p<0,01 ; * * p<0,001$. Vastastikmõju puudumise korral on taust hall. 
Noorimad kirjutajad vajavad erilist individuaalset tähelepanu: tingliku koondindeksi individuaalsed näitajad erinevad 5. klassis kuni neli korda ning üksikmuutujate standardhälve on alati suurem kui muudes vanuserühmades, kuid 11. klassis kõigub koondindeks ainult poolteist korda. Teiselt poolt ei saa süntaksit pidada ka 5. klassi kirjutiste hindeobjektiks, kuid hinnet võiks see loovkirjutistes juba mõjutada ja see viitab vajadusele süveneda süntaksi ja õpetajahinde seostesse.

Süntaksi koondindeksi poolest 5. ja 7. klass ei erine, nagu see ilmnes sõnavaragi puhul (Kerge jt 2014). Murdeea algupoole keelearengu seisak kinnitab Nippoldi jt (2005) vaba ja asjaliku vestluse süntaksi pikiuurimust (varajasest koolieast täiskasvanueani), kus just 13 aasta vanuses ilmneb žanrist sõltumatu tagasilöök kõrvallausetüüpide esinemuses, sisuüksuste määras ja ka lausestustiheduses (ibid.: 1054-1055). Vaid paar tunnust viitab 7. klassis kasvanud keelekogemusele: kahanenud on individuaalsete tulemuste hajusus, oluline väike erinevus on pikkade sõnade osatähtsuses $(r=0,33 ; p=0,004)$ ja nõrgalt-väheoluliselt erineb ka sõnavariatiivsus $(r=0,26 ; p=0,02)$. Siiski näitab uurimus tervikuna, et statistiliselt olulist kirjutusoskuse edenemist 11-14 aasta vanuses ei toimu. Kuna probleem ei ole õpetajate arvates ka 5. ja 7. klassi ühesuguses ülesandes (vt sissejuhatust), siis tuleb seda otsida mujalt kui uuringukorraldusest.

Psühhofüüsilise arengu teguritega võiks kirjaliku keelekasutuse suhtelist muutumatust teismeea algupooles seostada vaid kaudselt (vt Whitmire 2000; Shaffer, Kipp 2014: 187-189, 271, 495-498 vm). Kognitiivse arengu vaatenurgast on 5. klassi õpilased enamasti algaja kirjutaja tasemel (vt Ericsson jt 1993; Lee, Karmiloff-Smith 1996), kuid arengule võib viidata 7. klassi tulemuste osati väiksem individuaalne varieeruvus.

Keelearengu suhteline seisak varases murdeeas võib seostuda isiksuse arenguga. Isikuomaduste muutused murdeeas on küll väiksed, kuid isikuomadusi moodustavate joonte koosesinemus (isiksuse struktuur) erineb täiskasvanute omast enim just kõnealuses eas: 6. klassi õpilasel on sarnasusi täiskasvanutega omaduste kongruentsikoefitsiendi järgi suhteliselt vähe, kuid 8. klassis juba gümnaasiumiga üsna sarnasel täiskasvanupärasel määral. (Mõttus jt 2011) Nähtuva seisaku keelearengus võib tingida ka see, et identiteedi kujunemise aeglane algusfaas (vt Shaffer, Kipp 2014: 439-441) muudab tähtsaks eakaaslased ja nendega samastumise slängi kaudu (Whitmire 2000: 4-5), st keeleloome ja -omandamise aktsent jäävad väljapoole koolikeelt. Usaldusväärseid tõlgendusi ja järeldusi saab 
siinsete andmete põhjal teha vaid arengupsühholoog, kuid juhuslikkuse välistamiseks tuleb eraldi korrata ka nooremate katset.

Arenenud ja oskuslik kirjutamine on nõudlik ja mitmetahuline protsess, mis koosneb tunnetuslikust ja tekstipädevusest, aga ka pädevusest inimsuhetes, ning on sellepärast algajatele kirjutajatele raske (Holliway, McCutchen 2004). Algajat kirjutajat iseloomustas siin uurimuses eakohaste mõtete suulisepärane spontaanne ülesmärkimise viis, millele osutasid mitmed muutujad. Teismeea algusele osutusid tüüpiliseks oskamatus lausungeid kirjalikeks lauseteks organiseerida - laused on kas väga pikad või tekst lühilauseteks hakitud - ning domineeriv suulisepäraselt verbiline stiil. Samas on iseloomulik, et 5. klassi lause pikkus ja lausestustihedus võivad näitajatelt sarnaneda 11. klassi omadega.

Kõigest eeltoodust järeldame, et tuleb uurida ja võrrelda keskmiste või äärmuslike näitajate taga peituvaid kvaliteete nii samas andmekogus kui ka mujal (nt mitme aine kirjutistes ja täiskasvanute korpuse žanrites). Kvalitatiivne kirjeldus aitaks eristada rakenduslikult olulisi erinevusi earühmiti ja žanriti ning suhestada võimalikke keele- ja sisuhinde komponente. Samuti tuleks katset korrata sama ja teist liiki ülesannetega ning lasta kõrvutavalt kirjutada ka arvutis, sest kirjutamisülesanne ja kirjutamisvahend mõjutavad nii teksti loomise strateegia valikut kui ka valminud teksti kvaliteeti (Kellog 2008; Epting 2013).

Samas materjalis väärivad tähelepanu sidendus, süntaktiliste tarindite tüübid ning sõnaliikide sisemine vormiline variatiivsus. Kõik need on prooviuuringus andnud huvitavaid tulemusi. Omaette oluline teema on sõnamoodustus, mis seob süntaksit ja leksikat. Varem on nt üliõpilaskirjutiste pikiuuringus leitud, et deverbaalnoomenite määr on võrreldes ilukirjandusega neljakordne ja kasvab silmatorkavalt bakalaureuseastme 2.-3. õpiaastal (Baratta 2010); samuti eristab just sõnamoodustuse nappus kõrgtaseme L2-kirjutajate tekste eesti haritlasesseedest (Pajupuu jt 2010: 127).

Siinses uurimuses selgus nii nimisõnalise stiili domineerivuse kui ka pikkade sõnade (komplitseerituma ehitusega, sh tuletiste ja liitsõnade) määra oluline kasv teismeeas, kusjuures raamuurimuses on enne selgunud nii sõnavara üldine kui ka eraldi harvema sõnavara mitmekesistumine. Järelikult vajavad need näitajad kvalitatiivset uurimist ühe kimbuna. Samas on ulatuslike uurimuste järgi verbilise stiili suhteline dominant lühikeses tekstis loomulikum kui suuremas tekstimassiivis (Malvern jt 2004: 147 jj), 
mis tähendab, et arenguuuringus tähtsate individuaalsete keskmiste kõrval võiks samu tekste earühmiti võrrelda ka korpusena.

Tähelepanu vajab muugi metoodika. Eespool kirjeldasime võimalust kohandada Guiraud' indeksit sõnaliigi leksikaalse ja morfosüntaktilise varieeruvuse võrdluseks. Mõeldes kirjavigade uurimisele, tuleks ühtlasi arvestada pikkade sõnade hulgast välja sinna noorematel kirjavea tõttu sattunud keelendid. Nimisõnamääraga seotud muutujatest on eaga tugevaimas seoses just see määr ise, kuid samas on neist stiiliindeksil suhteliselt suurim standardhälve, mistõttu ühe žanriga piirduvais uurimustes võiks kõrvale jääda formaalsus. Meie tulemuste järgi tundub, et lausestustiheduse varem leitud ühtlane kasv võib olla kas individuaalse arengu pikiuurimusse sobiv tunnus (Scott 1988) või enam omane suulisele tekstile, eristades žanreid (Nippold jt 2005), nii et süntaktilist tihedust tuleks uurida mitmel meetodil. Alternatiive on eespool ka osutatud (Nir, Berman 2010).

Kirjutamisoskuse individuaalsed erinevused on gümnaasiumiõpilastel väidetavasti usaldusväärselt seotud töömälu mahuga (Vandenberg, Swanson 2007). Ajus toimuvate muutuste seisukohast näib töömälu võimsuse ehk mõttelõikude pikkuse kasv teise elukümnendi jooksul (abstraktse mõtlemise tekkest alates) olevat kirjutamisoskuse arengus fundamentaalse tähtsusega (Kuhn 2006). Kuhnile viidates saab samas vaid laiemalt teadvustada, et kirjutamisvilumuse tekkeks on vaja kirjutamisoskust süstemaatiliselt suunata selle osaoskuste suhtelise automatiseerimise poole, s.o sihipäraselt praktiseerida tekstide kirjutamist, jälgides seejuures kogenud kirjutajaid (vt Rijlaarsdam jt 2008). Kooliea kirjutiste areng nõuab kvalitatiivset seostamist ka emakeele omandamise-õppimise ning keeleteadlikkuse kasvu teemaga (vt arutlusi Ravid, Tolchinsky 2002; Bastos Figueriedo, Silva 2009). Uuritud parameetrite ealine muutus peegeldab laste üldist individuaalset arengut ning seda, kuidas kasvab kindlas laadis kirjutamise vilumus ja rohkem või vähem intuitiivne oskus sõnu seada. Kõik see kinnitab nii siinse kui ka viidatud süntaksiuurimuste lähtepunkti, kuid mitte nende kvaliteete ega seoseid õpetamise, harjutusviiside ja õppekavaga.

Teiselt poolt ei ole kvalitatiivseid andmeid, mil viisil mõjutab kirjutusoskust kool. Praegu räägitakse nii üldisest kui ka ainekirjaoskusest, kuid pole selge, kuidas jaguneb vastutus kirjaoskuse, sh kirjutusoskuse eest emakeeleõpetaja ja muude ainete õpetajate vahel (Krogh 2012). See jääb ebaselgeks ka kooliaegse keeleomandamise viidatud käsitlustes, 
paitsi õigekirja osas (vt Ravid, Tolchinsky 2002), mida me käesolevas ei uurinud. Siit kasvab välja vajadus uurida eri ainete kirjutiste spetsiifikat ja küsitluste toel ka ainekirjaoskuse olemuse mõistmist ühiskonnas.

Lisaks on sidumata kirjutusoskus ning lugemuse määr ja laad. Näiteks väidab suure õpetaja- ja õppejõukogemusega Jaanus Vaiksoo (2008), et „lugemise hind on kirjaoskus” ning „,kui sa ei loe, ei jää ka keel külge”. Seda mitmekesise ,lugemise hinda" mõtestavad Ravid ja Tolchinsky (2002) kui keeleteadlikkuse osa: retooriline paindlikkus ehk keelevahendite asjakohane valik eeldab kokkupuudet piisavalt laia ringi kirjaliku teksti liikidega. Selleks, et loetud tekstide mõju kirjutusoskusele teismeeas hinnata, tuleks Helin Puksandi teismeealugemuse (Puksand 2010) tüüpiline materjal earühmiti läbi töötada ning kirjeldada nii leitud kirjalike mõju- või sisendtekstide süntaksit kõrvuti õpilaste arenguga. Seni on küll uuritud eri vanustele suunatud õpitekste, kuid nende komplitseeritus ei seostu sihtrühma eaga (Puksand, Kerge 2012).

\section{Kokkuvõte}

Artikli keskmes oli kirjutiste süntaksi arengut iseloomustavate näitajate analüüs, mis koos samade õpilaste sõnavara käsitlusega (Kerge jt 2014) aitab statistika toel vastata, kuidas eesti teismelise keeleoskus põhijoontes areneb.

Sõnavaliku mitmekesistumise kõrval (ibid.) seostuvad kirjutaja eaga tugevasti mitmed muutujad, mis viitavad järjest keerukamale ja mitmekesisemale morfosüntaksile (OVIX, pikkade sõnade osatähtsus) ning keerukamale, sisutihedamale ja väljendustäpsemale tekstile (keerukusindeksi kasv, üha nominaalsem stiil ja kasvav formaalsus, deiktikute määra kahanemine). Funktsioonisõnade osatähtsus kahaneb klassist klassi, kuid see toimub vaid deiktikute arvelt. Erinevalt täiskasvanuist kasutavad õpilased ootamatult vähe kaassõnu. Konnektiive käsitletakse artiklina lähiajal.

Kirjalikku keelt tõepoolest õpitakse igas mõttes: eaga on järjest vähem kirjutamise spontaansusele osutavaid jooni. 5. klassi lause on veel suulisepäraselt pikk, näidates oskamatust kõnevoolu lauseteks liigendada, või kaldub teise äärmusse, koosnedes lihtsakoeliselt järjestatud ning tihti ja'ga algavatest lihtlausetest ja kaheosalisest liitlausetest, milles esineb mõni sagedasim sidend ja paari tüüpi kõrvallauseid. Muutujate suuri 
individuaalseid kõikumisi arvestades vajab just 5. klassi õpilane veel väga palju isiklikku tähelepanu.

Üldistatult on areng viiendast 7. klassini väga napp, kuid 7. klassis on muutujate hajuvus väiksem ning morfoloogia rikkam - enam on pikki sõnu ja veidi kasvab sõnavariatsioon. Stiiliindeks püsib samas ühtviisi haritlaste suulise läbirääkimisdialoogi ja teismemeilide tasemel. 5.-7. klassi tekst on spontaansusele omaselt verbiline ja sisaldab palju deiktikuid, olles seeläbi ka kontekstuaalsem (vähem formaalne).

Õpilaskirjutised muutuvad sisu- ja väljendustäpsemaks alles põhikooli 1õpus, mil muutujaväärtused oluliselt kasvavad ning süntaks on napi kvalitatiivse vaatluse järgi organiseeritum ja mitmekesisem.

Kõige ühtlasemini areneb süntaks teismeea nõrgimate individuaalsete näitajatega töödes. See suundumus ei kehti mingil määral parimates näidetes. Kõrgharidusega mittefiloloogide esseekorpuse kui haritud kirjutiste loomuliku etaloni tasemele ei jõua veel ka gümnaasiumiõpilaste mediaannäitajad. Ainult nominaalse ja verbilise stiili tasakaal on lähedal täiskasvanu toimetamata arvamuskirjutistele. Järelikult on vaja klassiti süvenenult ja kvalitatiivselt uurida, mispoolest erinevad ekstreemsete näitajatega õpilastekstid eakohaselt keskmiste näitajatega töödest.

Metoodika poolel osutus vähekõnekaks lausestustiheduse mõõdik, mida seni on kasutatud pikiuurimuses. Uuritud tekstide konstruktsioonide võrdlevaks kirjeldamiseks tuleb metoodikat mitmeti täiendada.

Uurimata on soo mõju süntaksierinevustele, ehkki valim seda lubab. Eraldi tuleks uurida tekstimuutujate mõju hindamisele, kasutades õpetajate kõrval mitmesuguseid eksperthindajaid ja kontrollides hindamisrubriikide mõistmist õpetajate eakohastes fookusgruppides. Küll aga saab juba praegu teha hindamiskoolitusi, et keelehinde rubriikide üle koos praktikutega otsustada, sest kirjutiste mõõdetavad parameetrid on nii sõnavara kui ka süntaksi poolelt teada.

Kvalitatiivse uurimuse jaoks on materjali veel aastateks. Ees on õpilaskirjutiste arengukäigu võrdlus eesti keele kui teise keele omandamise astmetega.

\section{Tänuavaldus}

Täname kõiki koole, õpetajaid ja õpilasi, kelle najal kogu uurimus teoks sai, ning uurimuse rahastajat ETF-i (grant 8605 „Kirjutamise loomulikkuse mudel ja hindamine"). 


\section{Kirjandus}

Alamargot jt 2010 = Denis Alamargot, Sylvie Plane, Eric Lambert, David Chesnet. Using eye and pen movements to trace the development of writing expertise. Case studies of a seventh, ninth and twelfth grader, graduate student, and professional writer. - Reading and Writing 23 (7), 853-888.

Baratta, Alexander M. 2010. Nominalization development across an undergraduate academic degree program. - Journal of Pragmatics 42 (4), 1017-1036. http://dx.doi.org/10.1016/j.pragma.2009.08.007.

Berman, Ruth, Ludo Verhoeven 2002. Developing text-production abilities across languages, genre and modality. - Written Languages and Literacy $5(1), 1-43$.

Bastos Figueiredo, Sandra Andrade de, Carlos Fernandes da Silva 2009. Cognitive differences in second language learners and the critical period effects. - L1-Educational Studies in Language and Literature 9 (4), $157-178$.

Björnsson, Carl-Hugo 1969. Lix på Danska. Stockholm: Pedagogiskt centrum, Stockholms skolförvaltning.

Eesti keel 2011 = Õppekava. Põhikooli valdkonnaraamat. Eesti keel. Gümnaasiumi valdkonnaraamat. Eesti keel. Tallinn: REKK. http://www.oppekava. ee $>$ Abiks õpetajale (25.09.2013).

Epting jt 2013 = L. Kimberly Epting, Evan M. Gallena, Stephany A. Hicks, Elizabeth N. Palmer, Traci Weisberg. Read and think before you write: prewriting time and level of print exposure as factors in writing and revisjon. - Journal of Writing Research 4 (3), 239-259.

Ericsson jt $1993=\mathrm{K}$. Anders Ericsson, Ralf Th. Krampe, Clemens Tesch-Römer. The role of deliberate practice in the acquisition of expert performance. Psychological Review 100, 363-406. http://dx.doi.org/10.1037/0033295X.100.3.363.

Funke jt 2013 = Reinold Funke, Regina Wieland, Stephanie Schönenberg, Florian Melzer. Exploring syntactic structures in first-language education: effects on literacy-related achievements. - L1-Educational Studies in Language and Literature 13, 1-24.

Halliday, Michael A. K. 1994. An Introduction to Functional Grammar. Second Edition. London: Edward Arnold.

Heylighen, Francis, Jean-Marc Dewaele 2002. Variation in the contextuality of language: an empirical measure. - Foundation of Science 7, 293-340.

Holliway, David. R., Deborah McCutchen 2004. Audience perspective in young writers' composing and revising. - Revision Cognitive and Instructional Processes. Ed. Linda Allal, Lucile Chanquoy, Pierre Largy. (= Studies 
in Writing 13.) Boston, Dordrecht (Netherlands), New York: Kluwer, $87-101$.

Hulstijn, Jan H. 2011. Language proficiency in native and nonnative speakers: an agenda for research and suggestions for second-language assessment. Language Assessment Quarterly 8 (3), 229-249.

Hultman, Tor G., Margareta Westman 1977. Gymnasistsvenska. Lund: LiberLäromedel.

Kasik, Reet 1995. Õiguskeele lauseehitus. - Õiguskeel 1, 16-21.

Kerge, Krista 2002. Varieties of language and mother tongue teaching orientation. - Learning and Educational Media. Ed. Jaan Mikk, Veijo Meisalo, Hasso Kukemelk, Mike Horsley. (= The Third IARTEM Volume.) The International Association for Research on Textbooks and Educational Media, University of Tartu, 230-236.

Kerge, Krista 2010. Kirjažanrite keeleparameetrid mitme tekstiliigi taustal. Emakeele Seltsi aastaraamat 55 (2009). Peatoim. Mati Erelt. Tallinn: Teaduste Akadeemia Kirjastus, 32-62.

Kerge, Krista, Hille Pajupuu 2010. Text-types in speech technology and language teaching. - Analizar datos $>$ Describir variación / Analyzing data $>$ Describing variation. Ed. Bueno Alonso, Jorge L., Dolores González Álvarez, Úrsula Kirsten Torrado, Ana E. Martínez Insua, etc. Vigo: Universidade de Vigo (Servizo de Publicacións), 380-390.

Kerge jt 2014 = Krista Kerge, Anne Uusen, Halliki Põlda. Teismeea loovkirjutiste sõnavara ja selle hindamine. - Eesti Rakenduslingvistika Ühingu aastaraamat 10 (2014). Toim. Helle Metslang, Margit Langemets, MariaMaren Sepper. Tallinn: Eesti Rakenduslingvistika Ühing,157-175. http:// dx.doi.org/10.5128/ERYa10.10.

Krogh, Ellen 2012. Writing in the literacy era: Scandinavian teachers' notions of writing in mother tongue education. - L1-Educational Studies in Language and Literature 12 (special issue). A contribution to the inescapability of language. Ed. Iris Pereira, Brenton Doecke. 1-28.

Kuhn, Deanna 2006. Do cognitive changes accompany developments in the adolescent brain? - Perspectives on Psychological Science 1, 59-67. http://dx.doi.org/10.1111/j.1745-6924.2006.t01-2-.x.

Lee, Kang, Annette Karmiloff-Smith 1996. The development of external symbol systems: the child as annotator. - Perceptual and Cognitive Development. Ed. Rochel Gelman, Terry Kit-Fong Au. San Diego: Academic Press, 185-211. http://dx.doi.org/10.1016/B978-012279660-9/50024-5.

Malvern jt 2004 = David Malvern, Brian Richards, Ngoni Chipere, Pilar Durán. Lexical Diversity and Language Development. Quantification and Assessment. Hampshire, New York: Palgrave Macmillan.

Mõttus jt 2011 = René Mõttus, Jüri Allik, Anu Realo. Intelligentsuse psühholoogia. Tartu: Tartu Ülikooli Kirjastus. 
Nippold, Marilyn A. 2004. Research on later language development. International perspectives. - Language Development Across Childhood and Adolescence. Psycholinguistic and Crosslinguistic Perspectives. Ed. Ruth A. Berman. (= Trends in Language Acquisition Research 3.) Amsterdam: John Benjamins, 1-8. http://dx.doi.org/10.1075/tilar.3.04nip.

Nippold jt 2005 = Marilyn A. Nippold, Linda J. Hesketh, Jill K. Duthie, Tracy C. Mansfield. Conversational versus expository discourse: a study of syntactic development in children, adolescents, and adults. - Journal of Speech, Language, and Hearing Research 48, 1048-1064.

Nir, Bracha, Ruth A. Berman 2010. Complex syntax as a window on contrative rethorics. - Journal of Pragmatics 42 (3), 744-765.

Pajupuu jt 2010 = Hille Pajupuu, Krista Kerge, Lya Meister, Eva Liina Asu, Pilvi Alp. Naturalness of speaking and how to assess it. - Trames. Journal of the Humanities and Social Sciences 59 (2), 120-140. http://dx.doi. org/10.3176/tr.2010.2.02.

Puksand, Helin 2010. Tekstid, mida loevad teismelised. Teismeliste lugemisharjumuste kasutamine koolis. - Tekstid ja taustad VI. Tekstiuurimus ja kool. Toim. Krista Kerge. Tallinn: Tallinna Ülikool, Emakeeleõpetuse Infokeskus, 20-35.

Puksand, Helin, Krista Kerge 2012. Õpiteksti analüüs kirjaoskuse omandamise kontekstis. - Emakeele Seltsi aastaraamat 57 (2011). Peatoim. Mati Erelt. Tallinn: Teaduste Akadeemia Kirjastus, 162-217. http://dx.doi. org/10.3176/esa57.09.

Ravid, Dorit, Liliana Tolchinsky 2002. Developing linguistic literacy. - Journal of Child Language 29 (2), 417-447.

Rijlaarsdam jt 2008 = Gert Rijlaarsdam, Martine Braaksma, Michel Couzijn, Tanja Janssen, Mariet Raedts, Elke van Steendam, Anne Toorenaar, Huub van den Bergh. Observation of peers in learning to write: practice and research. - Journal of Writing Research 1 (1), 53-83.

Rogoff, Barbara 2003. The Cultural Nature of Human Development. New York: Oxford University Press.

Scott, Cheryl M. 1988. Spoken and written syntax. - Later Language Development. Ages Nine trough Nineteen. Ed. Marilyn A. Nippold. Austin: Pro-Ed., 49-95.

Scott, Cheryl M., Sharon L. Stokes 1995. Measures of syntax in school-age children and adolescents. - Language, Speech, and Hearing Services in Schools 26, 309-319.

Shaffer, David R., Katherine Kipp 2014. Developmental Psychology. Childhood and Adolescence. International Edition. Wadsworth Cengage Learning.

Ure, Jean 1971. Lexical density and register differentiation. - Applications of Linguistics. Selected Papers of the Second International Congress of 
Applied Linguistics, Cambridge 1969. Ed. George Perren, John L. M. Trim. London: Cambridge University Press, 443-452.

Uusen, Anne 2006. Põhikooli I ja II astme õpilaste kirjutamisoskus. Doktoritöö. Tallinn: Tallinna Ülikooli kirjastus.

Vaiksoo, Jaanus 2008. Lugemise hind. - Sirp 11. I.

Vandenberg, Robert, Lee H. Swanson 2007. Which components of working memory are important in the writing process? - Reading and Writing $20,721-752$.

Verspoor jt 2012 = Marjolijn Verspoor, Xioyan Xu, Monika S. Schmid. A dynamic usage based perspective on L2 writing development. - Journal of Second Language Writing 21 (3), 239-263.

Whitmire, Kathleen A. 2000. Adolescence as developmental phase: a tutorial. - Topics in Language Disorder 20 (2), 1-14. http://dx.doi. org/10.1097/00011363-200020020-00003.

Krista Kerge

eesti keele ja kultuuri instituut

Tallinna Ülikool

Narva mnt 25

10120 Tallinn

krista.kerge@tlu.ee

Halliki Põlda

eesti keele ja kultuuri instituut

Tallinna Ülikool

Narva mnt 25

10120 Tallinn

halliki.polda@gmail.com

Anne Uusen
kasvatusteaduste instituut
Tallinna Ülikool
Narva mnt 25
10120 Tallinn
uusen@tlu.ee
Helin Puksand
kasvatusteaduste instituut
Tallinna Ülikool
Narva mnt 25
10120 Tallinn
helin.puksand@tlu.ee




\title{
Development of syntactic parameters of teenage creative writing
}

\author{
Krista Kerge, Anne Uusen, \\ Halliki Põlda, Helin Puksand
}

Within the framework of literacy development (see e.g., Ravid \& Tolchinsky 2002), 159 Estonian students from grades 5 (11-12 years old), 7 (13-14), 9 (15$16)$ and 11 (17-18 years) experimentally wrote an argumentative text on social values. The data was described statistically.

The lexical parameters of the writings started to grow rapidly after grade 7 but did not reach the level of adults (see Kerge et al. 2014). The same goes for parameters suitable for describing richer morphosyntax (more affixation and compounding), such as OVIX indexing unique tokens, or the percentage of long words; more complex syntax, such as formality index based on the importance of noun phrases; dominance of the nominal versus verbal style; growth in lexical density (here pointing to the decline of the amount of functional words) or clausal density. Moreover, those parameters do not develop equally. In grade 5, parameter values (all typical of oral or spontaneous texts) pointed to students writing down thoughts in the order they occur. Although standard deviations were relatively smaller in grade 7, there was no significant difference between grades 5 and 7, except in the proportion of the long words and somewhat in OVIX values.

After grade 7, all parameter values grow abruptly and significantly. The development continues in the upper secondary school age but reaches the adult level only in nominal style dominance (cf. Kerge, Pajupuu 2010). The developmental curve found here is very close to what is described by Alamargot et al. (2010), and especially by Nippold et al. (2005).

Keywords: Estonian, argumentative text, cognitive and linguistic development, ratio of unique tokens, sentence length and complicacy, formality, lexical and clausal density, nominal and verbal style 